Acta Technologica Agriculturae 1

Nitra, Slovaca Universitas Agriculturae Nitriae, 2014, pp. 1-5

\title{
PHYSICOCHEMICAL AND MICROBIOLOGICAL CHARACTERISTICS OF SOME SAMPLES OF HONEY PRODUCED BY BEEKEEPERS IN ALGERIA
}

\author{
Noureddine ADJLANE ${ }^{*}$, Nizar HADDAD², Karima LAID AMEUR ${ }^{3}$, \\ Saida KESRAOUI', Djamila MOUSSAOUI' \\ 'University of M'hamed Bougara of Boumerdès, Algeria \\ ${ }^{2}$ National Centre for Agricultural Research and Extension, Jordan \\ ${ }^{3}$ Algerian Centre of Quality and Packaging Control, Algeria
}

\begin{abstract}
This study aims to evaluate the physicochemical and microbiological quality of 11 samples of locally produced honey harvested from bee colonies across different regions of Algeria. Honeys analyzed are characterized by their different floral origins. Want germs are total aerobic mesophilic flora, total coliforms, anaerobic bacteria Sulfito-Drive (clostridium), yeasts and moulds. Water content, $\mathrm{pH}$, the concentration of hydroxymethylfurfural and sucrose content were also measured. For the physicochemical properties, most of the samples meet the requirements of Codex Alimentarius. Microbiological results showed that there is heterogeneity in the load of microorganisms sampled. Honeys have a low microbial profile. Total coliforms and clostridium were not detected in any sample. For counting the total aerobic mesophilic flora (TAMF), two local and imported samples have a concentration greater than the standard TAMF. Yeasts and moulds were also present but at low levels, and figures in all but three samples were below the norm.
\end{abstract}

Keywords: analysis, local honey, microbiological quality, physicochemical properties

Honey is the natural sweet substance produced by bees (Apis mellifera) from the nectar of plants, from secretions of living parts of plants or from secretions of insects on living parts of plants, which the bees collect, transform by combining with specific substances of their own, deposit, dehydrate, store and leave to ripen and mature in honeycombs.

The composition of honey depends on floral origin. Prost (1987) reports that several factors may influence the chemical composition of honey, such as the nature of the soil, bee breed and physiological state of the colony. In general, the chemical composition of honey varies from one sample to another; generally, honey contains major and minor elements. To assess the varieties of honey, some chemical, microbiological and sensory pollen must be taken into account. Many studies have been reported on physicochemical and microbiological properties of honey worldwide (Bogdanov et al., 2004; Naman et al., 2005; Nevas et al., 2005; Iurlina and Fritz, 2005; Julius-Ndukum et al., 2006; Kanalaya and Wasu, 2009; Popa et al., 2009; Luo et al., 2010; Gulfraz et al., 2011; Vanhanen et al., 2011; Adjlane et al., 2013).

However, in Algeria, little work has been devoted to the study of properties of Algerian honeys (Ouchemoukh et al., 2007; Makhloufi et al., 2007; Benaziza and Schweitzer, 2010). Studies on microbiological quality are lacking. The main sources of microbial contamination are likely to include pollen, the digestive tract of bees, dust, air, soil, nectar and equipment. However, crop conditions are also considered a source of contamination for honey. These factors can be controlled by good hygiene practices of beekeepers.

The current study aims to evaluate the physicochemical and microbiological properties of some varieties of local honey.

\section{Material and methods}

\section{Samples of honey}

Analyses were performed on 14 honey samples collected between 2009 and 2010 from different regions of Algeria. Eleven samples are considered as unifloral honeys and the rest as multifloral honeys (Table 1 ).

\section{Physicochemical analyses}

The parameters measured in our study are $\mathrm{pH}$, water content, hydroxymethylfurfural (HMF) content and sugar content. All these analyses were performed for $\mathrm{pH}$, water content and sugar according to Codex Alimentarius (1981). For dosing HMF, the method is AOAC (2000).

Water content is measured using a refractometer. Refractive index depends on water content. Knowing the refractive index, one deduces the water content. If the measurement is made at a temperature different from $20^{\circ} \mathrm{C}$, the reading must be corrected to reduce the refractive index. The correction factor is 0.00023 per degree Celsius.

The determination of HMF is based on the UV absorbance of HMF at $284 \mathrm{~nm}$. In order to avoid the interference from other compounds at this wavelength, we determined the difference between the absorbance of a clear aqueous solution of honey and the same solution after the addition of bisulfite.

For the determination of sugars, we used the Bertrand method based on reducing properties of carbohydrates. It enables the determination of all known reducers such as glucose, fructose, lactose as well as carbohydrates. Sucrose, which is not a reducing agent, can be measured after hydrolysis which liberates the functions of reducing glucose and fructose. 
Table 1

Honey samples analysed in the study

\begin{tabular}{|l||c|c|c|}
\hline Sample number & Type of honey & Origin & Crop year \\
\hline \hline 1 & Jujube (Ziziphus jujuba) & Djelfa & 2010 \\
\hline 2 & Jujube (Ziziphus jujuba) & Djelfa & 2010 \\
\hline 3 & Peganum harmala & Al-Beidh & 2010 \\
\hline 4 & Orange (Citrus sinensis) & Blida & 2010 \\
\hline 5 & Jujube (Ziziphus jujuba) & Djelfa & 2010 \\
\hline 6 & Every flower & Boumerdès & 2010 \\
\hline 7 & Every flower & Tipaza & 2010 \\
\hline 8 & Every flower & Béjaia & 2010 \\
\hline 9 & Every flower & Bouira & 2011 \\
\hline 10 & Orange & Blida & 2011 \\
\hline 11 & Wild carrot (Daucus carota) & Médea & 2011 \\
\hline 12 & Cnicus (Cnicus benedictus) & Djelfa & 2010 \\
\hline 13 & Eucalyptus globulus & Alger & 2011 \\
\hline 14 & Every flower & Tizi-Ouzou & \\
\hline
\end{tabular}

The assay is performed in three steps:

- Reduction of Fehling's solution by reducing carbohydrates.

- Isolation of the formed copper.

- Determination of copper magnanimity.

The result is derived from a table established experimentally by Bertrand, connecting the isolated amount of carbohydrates.

\section{Microbiological analyses}

The objective was to determine and count the total aerobic mesophilic flora, coliforms, clostridium sulforeducers, osmophiles yeasts and moulds xerophytic. Dilutions to $10^{-3}$ were selected.

\section{Total aerobic mesophilic flora}

We brought aseptically $1 \mathrm{ml}$ of each decimal dilution $\left(10^{-1}\right.$, $10^{-2}, 10^{-3}$ ) in sterile Petri dishes. After that, we added about $15 \mathrm{ml}$ of agar and plate count agar (PCA) thoroughly mixed inoculum to the culture medium by rotating the Petri dishes and allowing the mixture to cool and solidify on a horizontal surface. Then, the plates are incubated at $30^{\circ} \mathrm{C}$ for 72 hours. Playback is carried out after $24 \mathrm{~h}, 36 \mathrm{~h}$ and $72 \mathrm{~h}$. Colonies are in TAMF lenticular mass (Sneath et al., 2006).

\section{Total coliforms}

Two repetitions of each treatment were run in sterile Petri dishes loaded with $15 \mathrm{ml}$ VRB agar (violet red bile) media and carefully mixed with $1 \mathrm{ml}$ of dilution; the mixture was left until it was solidified. We also prepared a control box with about $15 \mathrm{ml}$ of medium to control its sterility. After complete solidification, we cast on the surface of inoculated medium $4 \mathrm{ml}$ around VRB medium and then left it to solidify.

Incubation is carried out in an oven set at $30^{\circ} \mathrm{C}$ or $37^{\circ} \mathrm{C}$ for 24 to 48 hours. Coliform bacteria appear as a small mass of fluorescent colonies with a diameter of $0.5 \mathrm{~mm}$ (Harrigan and McCance, 1976).

\section{Clostridium sulfo-reducer}

We brought aseptically $5 \mathrm{ml}$ of each decimal dilution $\left(10^{-1}, 10^{-2}\right)$ in a sterile tube. Both tubes were then subjected to heating at $80^{\circ} \mathrm{C}$ for 10 minutes and immediately cooled in tap water in order to eliminate the vegetative cells and spores in the leave. A total of $15 \mathrm{ml}$ melted beef liver agar was mixed with two vials of sodium sulfite and iron alum and carefully shook to avoid air bubbles formation in the solution. The tubes were left for 30 minutes until the solution became solid; they were left for $48-72 \mathrm{~h}$ in the incubator with a stable temperature of $37^{\circ} \mathrm{C}$. Reading results in the appearance of black colonies was the indicator of positive reading. The result is shown as the number of spores in $1 \mathrm{ml}$ of product (Harrigan and McCance, 1976).

\section{Osmophilic yeasts}

In order to run the osmophilic yeasts test, a total of $0.1 \mathrm{ml}$ in three dilutions $\left(10^{-1}, 10^{-2}, 10^{-3}\right)$ was added to Petri dish containing the agar Whalley, spread with a sterile rake and incubated at $30{ }^{\circ} \mathrm{C}$ for $2-3$ days. The formation of round, shiny or curved yeast colonies was a positive indication (Sneath et al., 2006).

\section{Drought-resistant moulds}

To run the xerophilic mould test, a total of $0.1 \mathrm{ml}$ in three dilutions $\left(10^{-1}, 10^{-2}, 10^{-3}\right)$ was added to Petri dish, in addition to the culture medium MY50. Round spreading movement of the dish was run to ensure the proper mix and then left for the period of $48-96 \mathrm{~h}$ and temperature of $22^{\circ} \mathrm{C}$. According to the reading, moulds have a velvety appearance and are larger (Sneath et al., 2006).

\section{Results and discussion}

\section{Physicochemical properties}

The $\mathrm{pH}$ values of our honey samples ranged between 3.40 and 4.46 , with an average of $3.87 \pm 0.29$. Therefore, it was 
Table 2

Summary of physicochemical analyses

\begin{tabular}{|l||c|c|c|c|c|}
\hline Sample number & $\mathbf{p H}$ & Water content in \% & Amount of HMF in mg.kg & Reducing sugar content in \% & Sucrose in \% \\
\hline \hline 1 & 4.07 & 17.1 & 34.90 & 62.5 & 10.09 \\
\hline 2 & 3.67 & 18.2 & 11.87 & 63.69 & 4.24 \\
\hline 3 & 3.96 & 16.2 & 9.25 & 74.05 & 4.21 \\
\hline 4 & 3.64 & 17.8 & 41.26 & 66.46 & 5.9 \\
\hline 5 & 4.01 & 17.0 & 20.64 & 90.12 & 5.28 \\
\hline 6 & 4.18 & 18.2 & 10.68 & 62.5 & 2.91 \\
\hline 7 & 3.98 & 19.0 & 19.61 & 64.60 & 15.34 \\
\hline 8 & 3.86 & 18.6 & 48.97 & 66.23 & 10.69 \\
\hline 9 & 3.48 & 18.2 & 13.82 & 77.99 & 9.56 \\
\hline 10 & 3.79 & 15.4 & 1.28 & 81.05 & 5.59 \\
\hline 11 & 4.13 & 14.6 & 6.09 & 65.36 & 10.55 \\
\hline 12 & 4.46 & 14.6 & 32.51 & 86.42 & 5.25 \\
\hline 13 & 3.59 & 18.2 & 10.22 & 82.61 & 5.9 \\
\hline 14 & 3.40 & 18.6 & 33.46 & 84.47 & 4.12 \\
\hline
\end{tabular}

found the studied honeys are acidic. Our results are in the range indicated by Donadieu (1984) and Gonnet (1982), who reported that the acidic $\mathrm{pH}$ of honey is between 3.5 and 6. The $\mathrm{pH}$ of honey is related to the amount of ionisable acid therein $\left(\mathrm{H}^{+}\right.$ions), i.e. its mineral composition.

The $\mathrm{pH}$ is a measure that allows the determination of floral origin. The honey from nectar has $\mathrm{pH}$ between 3.5 and 4.5, and that from honeydew is between 5 and 5.5 (Gonnet, 1986). Therefore, our honeys are nectar honeys. The same author says that a low pH of about 3.5 for honey predetermines a fragile product for conservation; therefore, precautions must be taken. Honey with $\mathrm{pH} 5$ or 5.5 will keep better and longer.

The determination of water content gives an indication of the state of maturation and storage of honey. The water content of our samples varies between 14.6 and $19 \%$, with an average of $17.24 \% \pm 1.49$. According to Gonnet (1982), only honeys with water content less than $18 \%$ are good to keep. This is the case of samples $1,3,4,5,10,11$ and 12 . The rest of the samples have moisture content greater than 18 $\%$. These high concentrations can probably be explained by: - Early harvest of honey, that is to say, before they mature.

- The duration of stay of these honeys in ripeners.

- Conditions in which honey is produced, harvested, processed and stored in the hive is the case for sample no. 9, which comes from the region of Boumerdès characterized by high rates of atmospheric moisture, especially during the spring (harvest period of the sample). In this context, Gonnet (1993) reported that a high relative humidity during harvest makes it difficult for bees to dehumidify nectar, so producing a honey rich in water, unstable physically and biologically, and which may deteriorate rapidly. Louveaux (1968) reported that the extraction of honey in a relatively humid environment may cause moisture absorption. For HMF, it was found that honeys have HMF content between 1.28 and $48.97 \mathrm{mg} \cdot \mathrm{kg}^{-1}$, with an average of $7.15 \pm 3.57 \mathrm{mg} \cdot \mathrm{kg}^{-1}$. Samples 4 and 8 have higher rates of
HMF, exceeding $40 \mathrm{mg} \cdot \mathrm{kg}^{-1}$. High water content promotes the conversion of sugars into HMF (Marceau et al., 1994). We recorded a water content of $17.8 \%$ and $18.6 \%$ respectively. Gonnet (1963) reports that moderate heating (at about $35^{\circ} \mathrm{C}$ ) continued for several months as well as storage at room temperature for several years can lead to the formation of an appreciable amount HMF in honey. According to the results, the HMF content of all the honeys studied (except 4 and 8 ) meets the Codex Alimentarius standard.

The sucrose content of honey is in average $7.15 \% \pm 12.80$. According to White (1962), honey has a sucrose content variation from $0.25 \%$ to $7.57 \%$, with a maximum of $10 \%$. The sucrose content in the analysed samples complies with standards, except for samples 1, 7, 8 and 11 .

\section{Microbiological properties}

The FMAT concentration is very high in samples 4, 5, 6, 7 and 13. It is greater than 1,000 CFU. $g^{-1}$ (Table 3). These honeys are non-compliant because concentration in honey must be less than 1,000 CFU.g ${ }^{-1}$ (French standard ECOC0300092V, 2003). Tatsadjieu et al. (2005) report a number of TAMF ranging from $1.7 \times 108 \mathrm{CFU} \cdot \mathrm{ml}^{-1}$ to $5.13 \times 108 \mathrm{CFU}^{-\mathrm{ml}^{-1}}$ for honey from Cameroon. Iurlina and Fritz (2005) reported in a work on commercial apiary honey and those in Argentina a number of TAMF varying between 30 CFU.g - $^{-1}$ and 1,200 CFU.g ${ }^{-1}$ and from 60 CFU.g ${ }^{-1}$ to 1,100 CFU. $g^{-1}$ respectively. Naman et al. (2005) reported in a study on a number of Moroccan honeys a TAMF value between $10 \mathrm{CFU}^{-g^{-1}}$ and 2,102 CFU. $g^{-1}$. In Romania, Popa et al. (2009) found a value of less than $100 \mathrm{CFU} \cdot \mathrm{g}^{-1}$. The work of Omafuvbe and Akanbi (2009) performed on local honeys in Nigeria revealed a TAMF value between 103 CFU. $g^{-1}$ and 5,103 CFU. $g^{-1}$.

The results for counting the total coliforms in the samples indicate the absence of the latter in all the samples. The absence of total coliforms was also reported in the work of Rall et al. (2003) in Spain, lurlina and Fritz (2005) in Argentina 
Table 3 Results of the microbiological analysis

\begin{tabular}{|c|c|c|c|c|}
\hline Sample number & $\begin{array}{l}\text { Total mesophilic flora } \\
\text { in CFU. } \text { g }^{-1}\end{array}$ & Clostridium & $\begin{array}{l}\text { Osmophilic yeasts } \\
\text { in CFU. } g^{-1}\end{array}$ & $\begin{array}{l}\text { Xerophytic fungi } \\
\text { in CFU. } \mathrm{ml}^{-1}\end{array}$ \\
\hline 1 & $<10$ & absence & $9.10^{2}$ & 0 \\
\hline 2 & $<10$ & absence & $9.10^{2}$ & 0 \\
\hline 3 & $<10$ & absence & 0 & 117.10 \\
\hline 4 & $1,242.10$ & absence & $18.10^{2}$ & 0 \\
\hline 5 & 477.10 & absence & $9.10^{2}$ & 0 \\
\hline 6 & 162.10 & absence & $27.10^{2}$ & 0 \\
\hline 7 & $1,017.10$ & absence & $108.10^{2}$ & 342.10 \\
\hline 8 & $9.10^{2}$ & absence & 0 & 9.10 \\
\hline 9 & $<10$ & absence & 0 & 0 \\
\hline 10 & $<10$ & absence & $18.10^{2}$ & 9.10 \\
\hline 11 & $<10$ & absence & 0 & 0 \\
\hline 12 & $<10$ & absence & 0 & 0 \\
\hline 13 & $27.10^{2}$ & absence & $18.10^{2}$ & 126.10 \\
\hline 14 & $<10$ & absence & $27.10^{2}$ & 0 \\
\hline
\end{tabular}

and Naman et al. (2005) in Morocco. However, Omafuvbe and Akanbi (2009) in Nigeria have indicated their presence in honeys with a value between 0 CFU. $g^{-1}$ and 3.10 CFU.g ${ }^{-1}$.

Clostridium is an indicator of pollution or contamination of honey. Our results indicate the complete absence of these germs. In a study of local honey from Cameroon, Tatsadjieu et al. (2005) reported rates of Clostridium botulinum between 3 CFU.ml $^{-1}$ and 23 CFU.ml $^{-1}$. Nevas et al. (2005) reported its presence fluctuating in $26 \%$ of samples for honey in Denmark, $10 \%$ in Norway and $2 \%$ in Sweden.

The counting of osmophilic yeast reveals 90.102 and $108.10^{2}$ yeast. $g^{-1}$. Samples 4, 6, 7, 13 and 14 have a large number too, which alters the quality of honey after fermentation undergone by these microorganisms. These samples do not meet the standards. According to Gonnet (1982), where fermentation exists, it is due to yeast and osmophilic mould such as Saccharomycess rouxii, Aspergillus and Monascus bisporus echinulatus, which can be found in natural honey. These germs are mainly in nectar but also are introduced via accidental pollution after harvest.

For drought-tolerant fungi, their number was 90 and 3,420 cells. g $^{-1}$. Naman et al. (2005) detected below 100 CFU.g ${ }^{-1}$ in values of Moroccan honeys. Popa et al. (2009) reported a content not exceeding $40 \mathrm{CFU} \cdot \mathrm{g}^{-1}$. In the study conducted by Omafuvbe and Okanbi (2009), no mould contamination was detected.

\section{Conclusion}

This study is part of the deepening knowledge of the physicochemical composition and microbiological quality of our local honey. Among the quality criteria applied to honey, seven parameters were studied. All samples record levels of $\mathrm{pH}$ and water conform to Codex Alimentarius. Two samples have a HMF content that exceeds the norm of Codex Alimentarius $\left(40 \mathrm{mg}^{\mathrm{kg}} \mathrm{kg}^{-1}\right)$. For sucrose, there is a sample that records the content well above the norm (10\%). For yeasts, $29 \%$ does not meet the standard, which predisposes them to fermentation. For drought-tolerant fungi, $36 \%$ of samples have a high concentration. It would be very interesting in the future to develop laws that govern the quality of local honey and standardize the Algerian honeys to address the fraudulent importation of certain honeys of very poor quality.

\section{References}

ADJLANE, N. - AMEUR LAIN, K. - LECKSIR, N. - GHARABI, N. HADDAD, N. 2013. Detection of Paenibacillus larvae spores in honey samples from beekeepers of the central region of Algeria. In Journal of Microbiology, Biotechnology and Food Sciences, vol. 3, 2013, no. 1, pp. 81-83.

BENAZIZA, D. - SCHWEITZER, P. 2010. Caractérisation des principaux miels des régions du Nord de l'Algérie. In Cahiers Agricultures, vol. 19, 2010, no. 6, pp. 432-438.

BOGDANOV, S. - RUOFF, K. - ODDO, P. L. 2004. Physicochemical methods for the characterisation of unifloral honeys. In Apidologie, vol. 35, 2004, pp. 56-98.

DONADIEU, Y. 1984. Le miel. Ed. Malloine, 1984, 60 pp.

GONNET, M. 1963. L'hydroxyméthylfurfural dans les miels. Mise au point d'une méthode de dosage. Station expérimentale d'Apiculture, Ceyevct de Recherches agronomiques du Sud-Est, Montfavet (Vaucluse). 1963, 15 pp.

GONNET, M. 1982. Le miel; composition, propriétés, conservation. Ed. OPIDA. 1982, 30 pp.

GONNET, M. 1986. L'analyse des miels. Description de quelques méthodes de contrôle de qualité. In Bul. Tech. Apic, 54, vol. 13, 1986, no. 1, pp. 17-36.

GULFRAZ, M. - IFTIKHAR, F. - IMRANE, M. - ZEENAT, A. - ASIF, S. SHAH, S. 2011. Compositional analysis and antimicrobial activity of various honey types of Pakistan. In International Journal of Food Science and Technology, vol. 46, 2011, no. 2, pp. 263-667.

HARRIGAN, W. F. - MCCANCE, M. E. 1976. Laboratory methods in food microbiology. Academic Press Inc. (London) Ltd. 1976, pp. 66-78, 261-2. 
IURLINA, M.O - FRITZ, R. 2005. Characterization of micro organisms in Argentinean honeys from different sources. In International Journal of Food Microbiology, vol. 105, 2005, pp. 297-304.

JEAN-PROST, P. 1987. L'apiculture. Connaître l'abeille. Conduire le rucher. 6éme édition Lavoisier. 1987, 597 pp.

JULIUS-NDUKUM, A. - FLORENCE, F. - DELPHINE, D. - PINTA, J. ANTOINE, M. 2006. La qualité physicochimique et microbologique du miel de la zone soudano-guinéenne de l'Ouest Cameroun. In Revue africaine de biotechnologie, vol. 6, 2006, no. 7, pp. 908-913.

KANLAYA, K. - WASU, P. 2009. L'isolement des bactéries acétiques à partir du miel, Maejo. In International Journal of Science and Technology, vol. 3, 2009, no. 1, pp. 71-76.

LOUVEAUX, J. 1968. Composition propriété et technologie du miel, Les produits de la ruche in traité de biologie de l'abeille, Tome 03. Ed Masson et Cie. 1968, 389 pp.

LUO, Y.B. - MA, Q. - FENG, Y.Q. 2010. Stir rod sorptive extraction with monolithic polymer as coating and its application to the analysis of fluoroquinolones in honey sample. In Journal of Chromatography, vol. 1217,2010 , no. 22, pp. 3583-3589.

MAKHLOUFI, C. - SCHWEITZER, P. - AZOUZI, B. - PERSANO ODDO, L. - CHOUKRI, A. - LAAREDJ, H. 2007. Some properties of Algerian honey. In Apiacta, 2007, no. 42, pp. 73-80.

MARCEAU, J. - NOREAU, J. - HOULE, E. 1994. Les HMF et la qualité du miel. Volume 15, numéros 2. Rapport de la Fédération des Apiculteurs du Québec, service de zootechnie, MAPAQ. 1994, 4 p.

NAMAN, M. - FAID, M. - ABLOUNI, A. 2005. Les propriétés microbiologiques et physico-chimique des miels marocains. In Revue internationale de l'agriculture et de la biologie, 2005, no. 12 , pp. 773-776.

NEVAS, M. - HIELM, S. - LINDSTOM, M. - HOM, H. - KOIVULEHTO, K. - KORKEALA, H. 2005. High prevalence of Clostridium botulinum types $A$ and $B$ in honey samples detected by polymerase chain reaction. In Miocrobiologia, vol. 11, 2005, no. 3, pp. 343-350.
OMAFUVBE, B.O. - AKANBI, O. 2009. Microbiological and physicochemical properties of some commercial Nigerian honey. In African Journal of Microbiology Research, vol. 3, 2009, no. 12, pp. 891-896. OUCHEMOUKH, S. - LOUAILECHE, H. - SCHWEIZER, P. 2007. Physicochemical characteristics and pollen spectrum of some Algerian honeys. In Food Control, 2007, no. 18, pp. 52-58.

POPA, M. - VICA, M. - AXINTE, R. - GLEVITZKY, M. - VARVARA, S. 2009. Study concerning the honey qualities in Transylvania Region. In Annales Universitatis Apulensis Series Oeconomica, 2009, no. 2, pp. 1034-1040.

RALL, V. - BOMBO, A. - LOPES, T. - CARVALHO, I. - SILVA, M. 2003. Honey consumption in the State of Sâo Paulo: a risk to human health. In Anaerobe, 2003, no. 9, pp. 299-303.

SNEATH, P.H.A. - MAIR, N.S. - SHARP, M.E. - HOLT, J.G. 1986. Bergey's manual of systemic bacteriology. Vol. 2, edited by Williams and Wilkins, Baltimore, USA. 1986, pp. 1104-1207.

TATSADJIEU, N. L. - MBAWALA, A. - YAMPELDA, A. 2005. Influence du chauffage et du conditionnement sur la qualité microbiologique et les propriétés physico-chimiques des miels de quelques localités autour de Ngnoundéré,Cameroun'. In Revue de Association africaine de microbiologie et d'hygiène alimentaire, vol. 20, 2005, no. 58, pp. 51-57.

VANHANEN, L.P. - EMMERZ, A. - SAVAGE, G.P. 2011. Mineral analysis of mono-floral New Zealand honey. In Food Chemistry, vol. 128, 2011, no. 1, pp. 236-240.

WITH, J.W. 1962. Composition of American honeys. In Bulletin technique apicol., 1962, no. 1261, p. 20.

\section{Contact address:}

*Noureddine Adjlane, University of M'hamed Bougara of Boumerdès, Algeria Department of Biology, Faculty of Science, e-mail: adjlanenoureddine@hotmail.com 